\section{IJ§ER}

ISSN: 2149-5939
International Journal of Social Sciences and Education Research

Online, http://dergipark.gov.tr/ijsser

Volume: $2(2), 2016$

\title{
Behaviours of teachers that arouse violence in students: Imaginal violence
}

\author{
Nida Bayındır ${ }^{1} \quad$ Levent Sevi ${ }^{2}$
}

Received Date: $21 / 10 / 2015$

Accepted Date: 13 / 02 / 2016

\begin{abstract}
Besides its duty to maintain social change and transformation, education is also supposed to raise the new generation. Violence is a factor hindering these functions. To do away with this menace, perception of violence in the society should be determined so that preventive measures could be taken. This research aims to reveal teachers' behaviours that associate violence according to students' perceptions. The image a teacher displays knowingly or unknowingly may be perceived by students as subliminal messages with violence-content. The research is significant in that it reveals how violence penetrates into our lives implicitly. The research was applied on 119 students at $4^{\text {th }}$ grade of primary schools in the city of Kütahya during 2014-15 education period. According to the research results, 73,9\% of the students consider their teacher's walking up to them as violent behaviour, followed by his/her swearing and staring at child's eyes for 60,5\%. Accordingly, it is suggested that teachers should pay maximum attention to how their every single movement is perceived.
\end{abstract}

Keywords: Violence; Association; Behaviour; Teacher

\section{Introduction}

In today's societies, violence is one of the leading problems of humankind. Violence threatens the physical, psychological and sociological health of human beings. Although violence is defined by WHO (World Health Organization) as "the intentional use of physical force or power, threatened or actual, against oneself, another person, or against a group or community, that either results in or has a high likelihood of resulting in injury, death, psychological harm, maldevelopment or deprivation", it is, in fact, a relative equation with more constituents than what actually appears. Violence is the negative response of a human as a social being to conflicts s/he sometimes encounters while proving her/himself to the society and trying to form a healthy self (Ünalmış and Şahin, 2012, Ayan, 2007, Özgür et al., 2011).

From the first existence of humankind onwards, violence has appeared with a complicated structure fed with numerous factors. It is a pathology affecting negatively not only the exerciser and victim of violence but also those who witness violence. The most obvious victims of violence in society are children and they are exposed to the traumatic effects of violence in social life throughout their lives. Children spend most of their lives at school; therefore, schools become institutions with crucial responsibility for children to be able to socialize, solve problems, and be informed and enculturated. In these institutions, children are also supposed to gain certain accurate behaviours and develop a healthy personality as humans. Violence cases at schools and perception of violence defined in behaviours shape the phenomenon of violence in children, and

1 Assoc. Prof. Dr., Dumlupınar University, Education Faculty, Department of Elementary Education, KÜTAHYA/TURKEY, nida.bayindir@,dpu.edu.tr

${ }^{2}$ Lecturer, Dumlupınar University, School of Foreign Languages, KÜTAHYA/TURKEY, levent.sevi@dpu.edu.tr 
Bayındır, N., Sevi, L. (2016). Behaviours of teachers that arouse violence in students: Imaginal violence. International Journal of Social Sciences and Education Research, 2 (2), 670-675.

ultimately in the society (Furling and Morrison, 2000, Çubukçu and Dönmez, 2012, Özdemir and Sezgin, 2011)

Violence leaves deep scars in children. Besides its physical effects, it might also lead to psychological problems like stress and anxiety disorders. Students who are exposed to violence are seen to suffer from confidence problems, withdraw into themselves, be alienated from school and learning, escape from people, develop phobias, have serious concerns about their future and fail academically. It is a well-known truth that there are attitudes and behaviours of violence at school. However, considering the fact that violence is a learned behaviour passing from one generation to the next, the danger of perception of violence that gives preconceived and subliminal messages can be understood better (Kılıç and Atli, 2011, Pişkin, 2010, Kızmaz, 2006, Chen and Astor, 2010).

The fact that children are especially exposed to violence has given rise to a global social sensitivity and so scientific research to determine and prevent violence has intensified. However, it is seen that current research and definitions are only descriptive and directed to such state of violence that has turned into action. Therefore, not enough extensive research exists on the causes of violence and its effects on perception, which means that the perceptive dimension that forms that basis of violence and exacerbates it is inadvertently neglected (Atmaca and Öntaş, 2014, Çınkır and Kepenekçi, 2003, Kılıç, 2012, WHO, 2002, Gökler, 2009, MEB (Ministry of Education), 2007, Yavuzer, 2001).

According to the research reports of TBMM (Turkish Grand National Assembly) on the increasing violence tendencies among teenagers in Turkey that investigated the violence cases students were exposed to during 2006-07 education period, 22\% of the students were exposed to physical violence while 53\% were subject to verbal violence. Moreover, the research conducted by the Ministry of Health and Security General Directorate also shows that violence leads to serious problems in Turkey (Sümer and Aydın, 1999, Pişkin, 2006, Kocacık, 2001, TBMM, 2007, Turkish Institution of Family Research of Prime Ministry, 1998, Violence Reports, 2014).

Violence at school is not only limited to physical, emotional, sexual, verbal and economic violence by student on student or by teacher on student. Neglecting this fact is a crucial handicap preventing violence at school from being seen clearly and precisely. Research (İbiloğlu, 2012, Avcı and Güçray, 2010, Yurtal and Cenkseven, 2007, Cenkseven and Yurtal, 2008, Pişkin, 2002, Gözütok, 1993, Bulut, 2008, Hatunoğlu and Hatunoğlu, 2005, Ünal and Çukur, 2011, Yurtal and Artut, 2010, Çakmak, 2011, MEB 2011) is mostly student-oriented. In fact, violence by teachers on students should be researched at least just as much. No research has been seen in the literature researching violence behaviors that form the perception of violence and lead to associations upon teacher image.

\section{Method}

The research aims to determine the violence elements of teachers' behaviors according to students' perceptions. For this purpose, to obtain the perception of violence, the research was structured on single screening model seeking answers to the question "what are the behaviors that arouse violence in you?" asked for students to describe their teachers' behaviors. The population of the research is composed of $4^{\text {th }}$ grade primary school students in Kütahya during 2014-15 education period. However, considering time, cost and existing limitations, a sampling group of 112 
Bayındır, N., Sevi, L. (2016). Behaviours of teachers that arouse violence in students: Imaginal violence.

International Journal of Social Sciences and Education Research, 2 (2), 670-675.

students to represent the population was decided upon ease of accessibility. The data were gathered through a survey developed by the researchers. The questionnaire form was developed on the basis of the behaviors of teachers considered by students to involve violence. The items of the questionnaire were designed in such a way to reflect the existing case. The questionnaire was restructured upon the opinions of experts to maintain structural validity and was then conducted on the sampling. Its Cronbach Alpha value was found 0,84. The data were interpreted using analyses of percentage, frequency, standard deviation and means. During this interpretation, the values $50 \%$ and above were taken as reference.

\section{Findings}

The findings of the research conducted to determine the behaviors of teachers arousing violence according to students' perceptions are given below.

Table 1. Reliability Analysis

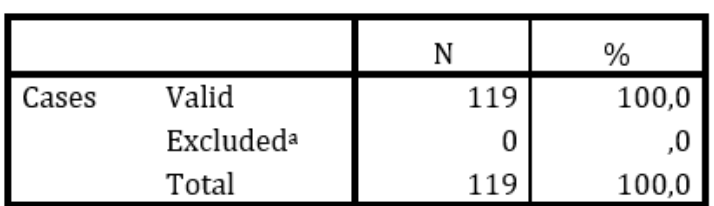

a. Listwise deletion based on all variables in the procedure.
Reliability Statistics

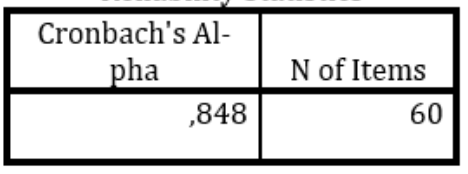

The cronbach alpha value is within the reliability range.

Table 2. Items for the perceptions of students about the behaviors of teachers evoking violence

\begin{tabular}{|l|c|c|c|c|c|c|c|}
\hline \multicolumn{1}{|c|}{ Items \% } & $\mathbf{1}$ & $\mathbf{2}$ & $\mathbf{3}$ & $\mathbf{4}$ & $\mathbf{5}$ & $\mathbf{M}$ & $\mathbf{S d}$ \\
\hline 1-Being afraid of his/her facial expression & 6,7 & 38,7 & 16,0 & 35,3 & 3,4 & 2,89 & 1,06 \\
\hline 2- Being afraid of his/her clothing & 27,7 & 28,6 & 17,6 & 20,2 & 5,9 & 2,47 & 1,25 \\
\hline 3-His/her loud voice & & 15,1 & 25,2 & 29,4 & 30,3 & 3,74 & 1,05 \\
\hline 4-Raising his/her voice suddenly & 2,5 & 4,2 & $\mathbf{5 3 , 8}$ & 12,6 & 26,9 & 3,57 & 1,01 \\
\hline 5-His/her threatening looks & 0,8 & 7,6 & 11,8 & 35,3 & 44,5 & 4,15 & 0,96 \\
\hline 6-His/her walking up to the child & 0,8 & 1,7 & 4,2 & 19,3 & $\mathbf{7 3 , 9}$ & 4,63 & 0,72 \\
\hline 7- His/her reprimanding & 0,8 & 7,6 & 7,6 & 24,4 & $\mathbf{5 9 , 7}$ & 4,34 & 0,96 \\
\hline 8- His/her branding & 4,2 & 15,1 & 14,3 & $\mathbf{5 2 , 1}$ & 14,3 & 3,57 & 1,04 \\
\hline 9- His/her verbal intervention (Don'ts) & 3,4 & 8,4 & 15,1 & 48,7 & 24,4 & 3,82 & 1,00 \\
\hline 10- His/her giving too much homework & 10,1 & 19,3 & 21,3 & 35,3 & 13,4 & 3,22 & 1,20 \\
\hline 11- His/her threatening & & 2,5 & 3,4 & 42,0 & $\mathbf{5 2 , 1}$ & 4,43 & 0,68 \\
\hline 12- His/her mocking & 9,2 & 26,1 & 31,9 & 27,7 & 5,0 & 2,93 & 1,05 \\
\hline 13- His/her sudden gestures & 5,0 & 16,0 & 21,8 & 42,9 & 14,3 & 3,45 & 1,07 \\
\hline 14- His/her insulting & 4,2 & 14,3 & 16,0 & 47,1 & 18,5 & 3,61 & 0,88 \\
\hline 15- His/her twitting & 1,7 & 2,5 & 12,6 & 39,5 & 43,7 & 4,21 & 0,88 \\
\hline 16- His/her humiliating & 10,9 & 12,6 & 25,3 & 30,3 & 10,9 & 3,17 & 1,13 \\
\hline 17- His/her manhandling & 6,7 & 13,4 & 12,6 & 16,0 & $\mathbf{5 1 , 3}$ & 3,91 & 1,33 \\
\hline 18- His/her acting as if s/he is going to slap or kick & 1,7 & 7,6 & 11,8 & 23,5 & $\mathbf{5 5 , 5}$ & 4,23 & 1,03 \\
\hline 19- His/her swearing & 1,7 & 3,4 & 10,9 & 23,5 & $\mathbf{6 0 , 5}$ & 4,37 & 0,92 \\
\hline 20- His/her excessive restrictions & 4,2 & 20,2 & 31,9 & 29,4 & 14,3 & 3,29 & 1,07 \\
\hline 21- His/her frightening speech & 4,2 & 13,4 & 19,3 & 48,7 & 14,3 & 3,55 & 1,03 \\
\hline 22-Gnashing his/her teeth & 2,5 & 5,9 & 17,6 & 19,3 & $\mathbf{5 4 , 6}$ & 4,17 & 1,07 \\
\hline 23-Cracking his/her knuckles & 7,6 & 15,1 & 28,6 & 41,2 & 7,6 & 3,26 & 1,05 \\
\hline 24- Stamping his/her heels & 8,4 & 33,6 & 29,4 & 24,4 & 4,2 & 2,82 & 1,03 \\
\hline 25- His/her swaggering & 4,2 & 23,5 & 26,9 & 37,0 & 8,4 & 3,21 & 1,03 \\
\hline
\end{tabular}


Bayındır, N., Sevi, L. (2016). Behaviours of teachers that arouse violence in students: Imaginal violence. International Journal of Social Sciences and Education Research, 2 (2), 670-675.

\begin{tabular}{|c|c|c|c|c|c|c|c|}
\hline $\begin{array}{l}\text { 26- Not being able to control his/her gestures } \\
\text { and mimes }\end{array}$ & 2,5 & 25,2 & 21,8 & 38,7 & 11,8 & 3,31 & 1,05 \\
\hline $\begin{array}{l}27-\text { His/her eyelids or eyebrows twitching in- } \\
\text { voluntarily }\end{array}$ & 4,2 & 13,4 & 16,0 & 49,6 & 16,8 & 3,61 & 1,05 \\
\hline 28- His/her use of cliché (Got it?) & 5,0 & 10,1 & 9,2 & 52,9 & 22,7 & 3,78 & 1,06 \\
\hline 29- His/her swinging rosary, keys & 2,5 & 8,4 & 47,9 & 34,5 & 6,7 & 3,34 & 0,82 \\
\hline 30- His/her speaking more slowly than normal & 0,8 & 5,9 & 8,4 & $\mathbf{5 5 , 5}$ & 29,4 & 4,06 & 0,83 \\
\hline 31- His/her putting on airs & 9,2 & 15,1 & 16,0 & 40,3 & 19,3 & 3,45 & 1,22 \\
\hline 32- His/her giving names & 4,2 & 16,8 & 23,5 & 40,3 & 15,1 & 3,45 & 1,07 \\
\hline 33- His/her intimidations & 0,8 & 2,5 & 1,7 & 41,2 & 53,8 & 4,44 & 0,73 \\
\hline 34- His/her continuous questions & 2,5 & 3,4 & 16,0 & 42,9 & 35,3 & 4,05 & 0,93 \\
\hline 35- His/her spontaneous prohibitions & 5,0 & 25,2 & 26,1 & 21,8 & 21,8 & 3,30 & 1,21 \\
\hline 36- His/her wagering & 3,4 & 9,2 & 16,8 & 49,6 & 21,0 & 3,75 & 0,99 \\
\hline 37- His/her continuous conditions (if, unless) & 0,8 & 5,9 & 14,3 & 53,8 & 25,2 & 3,96 & 0,84 \\
\hline 38- His/her forcing child to do something & 6,7 & 18,5 & 19,3 & 30,3 & 25,2 & 3,48 & 1,07 \\
\hline 39- His/her continuous hushes & 4,2 & 17,6 & 36,1 & 26,1 & 16,0 & 3,31 & 1,07 \\
\hline 40- His/her continuous interrogations & 4,2 & 11,8 & 21,8 & 42,9 & 19,3 & 3,61 & 1,05 \\
\hline 41- His/her continuous critics & 3,4 & 7,6 & 31,1 & 33,6 & 24,4 & 3,68 & 1,03 \\
\hline 42- His/her continuous commands & 3,4 & 7,6 & 26,9 & 37,0 & 25,2 & 3,73 & 1,03 \\
\hline 43- His/her dispraising a child to his/her peer & 2,5 & 10,1 & 25,2 & 38,7 & 23,5 & 3,70 & 1,01 \\
\hline 44- His/her insults towards child's gender & 1,7 & 5,9 & 9,2 & 47,9 & 35,3 & 4,09 & 0,91 \\
\hline 45- His/her stuttering out of anger & & 3,4 & 3,4 & 35,3 & $\mathbf{5 8 , 0}$ & 4,47 & 0,72 \\
\hline 46- His/her frequent and noisy breathing & 5,9 & 10,9 & 37,0 & 26,1 & 20,2 & 3,43 & 1,10 \\
\hline 47- His/her long and meaningless looks & 0,8 & 15,1 & 26,1 & 39,5 & 18,5 & 3,59 & 0,98 \\
\hline 48- His/her long and sophisticated sentences & 14,3 & 15,1 & 29,4 & 33,6 & 7,6 & 3,05 & 1,17 \\
\hline 49- His/her frightening examples & 1,7 & 3,4 & 10,9 & 23,5 & 60,5 & 4,37 & 0,92 \\
\hline $\begin{array}{l}\text { 50- His/her unhappy and thoughtful appear- } \\
\text { ance }\end{array}$ & 5,9 & 7,6 & 16,0 & 52,1 & 18,5 & 3,69 & 1,04 \\
\hline 51- His/her staring at child's eyes & 2,5 & 6,7 & 15,1 & 15,1 & 60,5 & 4,24 & 1,09 \\
\hline 52- His/her brooding with a faraway look & 7,6 & 18,5 & 21,8 & 39,5 & 12,6 & 3,31 & 1,14 \\
\hline $\begin{array}{l}53 \text { - His/her acting as if } \mathrm{s} / \mathrm{he} \text { is going to throw } \\
\text { something }\end{array}$ & 4,2 & 5,9 & 15,1 & 21,8 & 52,8 & 4,13 & 1,13 \\
\hline 54- His/her deep voice & 10,9 & 15,1 & 21,8 & 38,7 & 13,4 & 3,28 & 1,20 \\
\hline $\begin{array}{l}55-\text { His/her acting as if } \mathrm{s} / \text { he is going to hit } \\
\text { with an object }\end{array}$ & 4,2 & 10,9 & 8,4 & 22,7 & 10,1 & 4,10 & 1,19 \\
\hline 56- His/her sworn speech & 10,1 & 10,9 & 19,3 & 43,7 & 16,0 & 3,44 & 1,18 \\
\hline 57- His/her abusing & 5,0 & 18,5 & 15,1 & 46,2 & 15,1 & 3,47 & 1,11 \\
\hline $\begin{array}{l}\text { 58- His/her frightening children with low } \\
\text { marks }\end{array}$ & 5,0 & 25,2 & 26,1 & 14,3 & 29,4 & 3,37 & 1,28 \\
\hline 59- His/her not letting children have a break & 7,6 & 35,3 & 18,5 & 29,4 & 9,2 & 2,97 & 1,15 \\
\hline 60- His/her practical jokes & 5,0 & 18,5 & 17,6 & 20,2 & 38,7 & 3,68 & 1,29 \\
\hline
\end{tabular}

According to the research findings, $73,9 \%$ of the students regard the teacher's walking up to the child as behavior of violence, followed by his/her swearing, his/her frightening examples and his/her staring at child's eyes $(\% 60,5)$, his/her reprimanding $(\% 59,7)$, his/her stuttering out of anger (\%58), his/her acting as if s/he is going to slap or kick.

\section{Conclusion and suggestions}

According to the research results, students consider their teacher's physical behaviors as those involving the most violence followed by verbal behaviors. Therefore, students shape their perception of violence when their teachers actualize violence directly. Nevertheless, their assessment of the questionnaire items also shows that they in fact experience unknowingly the behaviors that could involve violence. The research results also indicate that teachers should not only abstain 
Bayındır, N., Sevi, L. (2016). Behaviours of teachers that arouse violence in students: Imaginal violence. International Journal of Social Sciences and Education Research, 2 (2), 670-675.

from behaviors involving violence, but they should also avoid behaviors that could be perceived as violent by students. To achieve this, teachers should know the behaviors that could give rise to worry, fear, hatred, etc. and avoid displaying such behaviors in the presence of students. With the help of pre- and in-service training about student expectations, forming and sustaining mental health and personality, teachers should enhance their emphatic thinking skills, should pay maximum attention to courtesy and ceremony and, above all, should always sustain the democratic atmosphere in class.

\section{References}

Atmaca, K. ve Öntaş, T. (2014). Velilerin öğretmenlere uyguladığı şiddete yönelik nitel bir araştırma, Anadolu Eğitim Liderliği Ve Öğretim Dergisi, 2(1), 27-62.

Avcı, R. ve Güçray, S. S. (2010). Şiddet davranışı gösteren ve göstermeyen ergenlerin ailelerinin aile işlevleri, aile bireylerine ilişsin problemler, öfke ve öfke ifade tarzları açısından incelenmesi, Kuram Ve Uygulamada Eğitim Bilimleri, 10(1), 45-76.

Ayan, S. (2007). Aile içinde şiddete uğrayan çocukların saldırganlık eğilimleri, Anatolian Journal of Psychiatry, 8, 206-214.

BAŞBAKANLIK AILE ARAŞTIRMA KURUMU, (1998). Aile içinde ve toplumsal alanda şiddet, 113, Ankara. http://ailetoplum.aile.gov.tr/data/ 54293ea2369dc32358ee2b25/kutuphane_33_aile_icinde_ve_toplumsal_alanda_siddet.pdf. (May, 2014)

Bulut, S. (2008). Öğretmenden öğrenciye yönelik olan fiziksel şiddet: Nicel bir araştırma. Abant Izzet Baysal Üniversitesi Eğitim Fakültesi Dergisi, (8(1), 105-118.

Cenkseven, Ö. F. ve Yurtal, F. (2008). Zorba, kurban ve olumlu özellikler taşıyan ergenlerin aile özelliklerinin incelenmesi, Kuram Ve Uygulamada Eğitim Bilimleri Dergisi, 8, 805-832.

Chen, J. K. ve Astor, R. A. (2010). School violence in Taiwan: examining how western risk factors predict school violence in an Asian culture, Journal of Interpersonel Violence, 25(8), 1388-1410.

Çakmak, M. (2011). Changing roles of teachers: prospective teachers' thoughts, Education and Science, 36(159), 14-24.

Çınkır, Ş. ve Kepenekcı, Y. K. (2003). Öğrenciler arası zorbalık. Kuram Ve Uygulamada Eğitim Yönetimi, 34, 236-253.

Çubukçu, Z. ve Dönmez, A. (2012). İlköğretim okul yöneticilerinin şiddet türlerine yönelik görüşleri ve şiddetle başa çıkma yöntemleri, Kuram Ve Uygulamada Eğitim Yönetimi, 18,(1), 37-64.

Gökler, R. (2009). Okulda akran zorbalığı, Uluslararası Insan Bilimleri Dergisi, 6(2), 511-537.

Gözütok, F. D. (1993). Disiplin sağlamada öğretmen davranışları, Ankara Üniversitesi Eğitim Bilimleri Fakültesi Dergisi, 25. 703-711.

Hatunoğlu, B. Y. ve Hatunoğlu, A. (2005). Öğretmenlerin fiziksel cezalandırmaya ilişkin görüşleri, Atatürk Üniversitesi Sosyal Bilimler Enstitüsü Dergisi, 6(2), 105-115.

İbiloğlu, A. O. (2012). Aile içi şiddet, Psikiyatride Güncel Yaklaşımlar. 4(2), 204-222.

Kılıç, E. Z. (2012). Ergenlerde şiddet kullanımı: bireysel ve ailesel etkenler. Nöropsikiyatri Arşivi, 49, 260265.

K1lıç, M. ve Atli, A. (2011). İlköğretim ve ortaöğretim okullarında yaşanmış şiddetin gazetelere yansımalar1, E-Journal Of New World Sciences Academy, 6(1), 1284-1294. 
Bayındır, N., Sevi, L. (2016). Behaviours of teachers that arouse violence in students: Imaginal violence. International Journal of Social Sciences and Education Research, 2 (2), 670-675.

Kızmaz, Z. (2006). Okullardaki şiddet davranışının kaynakları üzerine kuramsal bir yaklaşım, CÜ, Sosyal Bilimler Dergisi, 30(1), 47-70.

Kocacık, F. (2001). Şiddet olgusu üzerine, CÜ, İktisadi Ve Idari Bilimler Dergisi, 2(1), 1-7.

MEB, (2007). Ortaöğretim okullarında görevli yöneticilerin şiddet konusundaki bilgi ve becerilerine ilişkin mevcut durum analizi, EARGED, Ankara. http://www.meb.gov.tr/earged/earged/siddet_arastirmasi_yonetici.pdf. Haziran'da alıntılandı

MEB, (2011). Güvenli eğitim ortamlarının sağlanması: Okulda şiddetin önlenmesi araştırması, Altındağ Araştırma Raporu http://mebk12.meb.gov.tr/meb_iys_dosyalar/06/01/334395/dosyalar/2012_12/18012831_altndaiddetaratrmas.pdf. Mayıs 2014'da alıntıland

Özdemir, S. ve Sezgin, F. (2011). İlköğretim okulu öğrencilerinin yönetici ve öğretmen desteği, algılanan şiddet ve okul memnuniyetine ilişkin görüşleri, İnönü Üniversitesi Ĕ̆itim Fakültesi Dergisi, 12(2), 181199.

Özgür, G. Yörükoğlu, G. Arabac1, B. Y. (2011). Lise öğrencilerinin şiddet algıları, şiddet eğilim düzeyleri ve etkileyen faktörler, Psikiyatri Hemşireliği Dergisi, 2(2), 53-60.

Pişkin, M. (2002). Okul zorbalığı: Tanımı, türleri, ilişkili olduğu faktörler ve alınabilecek önlemler, Kuram Ve Uygulamada Ĕ̈itim Bilimleri Dergisi, 2, 533-551.

Pişkin, M. (2006). Okul şiddeti: Tanımı, yaygınlığı ve önleme stratejileri, Kamuda Sosyal Politika, 1(2), 43-62.

Pişkin, M. (2010). Examination of peer bullying among primary and middle school children in Ankara. Education And Science, 35(156), 175-189.

Sümer, Z. H. ve Aydın, G. (1999). Incidence of violence in Turkish school: A review. International Journal For The Advancement Of Counselling, 21,335-347.

Ünal, H. ve Çukur, C. Ş. (2011). The effects of shool bonds, discipline techniques in school and victimization on deliquency of high school students. Educational Sciences: Theory and Practice, 11(2), 560-570.

Ünalmış, M. ve Şahin, R. (2012). Şiddete yönelik tutum ve okul zorbalığı, Uluslararası Cumhuriyet Dergisi, 1(1), 63-71.

TBMM, Araştırma Komisyonu, (2007). Türkiye'de ortaöğretime devam eden öğrencilerde ceza ve infaz kurumlarında bulunan tutuklu ve hükümlü çocuklarda şiddet ve bunu etkileyen etkenlerin saptanması. http://www.kom.pol.tr/tubim/SiteAssets/Sayfalar/Di\%C4\%9Fer-Raporlar/_tbmm_cocuk_artan.pdf. (April, 2014)

WHO, (2002). World report on violence and health http://whqlibdoc.who.int/hq/2002/9241545615.pdf. (April, 2014)

Yavuzer, Y. (2001). Okulda saldırganlık/şiddet: Okul ve öğretmenle ilgili risk faktörleri ve önleme stratejileri, Milli Ĕgitim, 192, 43-61.

Yurtal, F. ve Artut, K. (2010). An investigation of school violence through turkish childrens drawings. Journal Of Interpersonel Violence, 25,(1), 50-62.

Yurtal, F. ve Cenkseven, F. (2007). İlköğretim okullarında zorbalığın yaygınlığı ve doğası, Psikolojik Danışma Ve Rehberlik Dergisi, 3(28), 1-13.

\section{$\underline{\text { Raporlar }}$}

Çocuğa yönelik şiddetin önlenmesi teknik destek projesi raporu, (2014). http://siddetinonlenmesi.meb.gov.tr/meb_iys_dosyalar/2014_09/04105755_literaturtaramasi.pdf. (Mayl, 2014) 